\title{
Evaluation of the ERM application in Turkey within the framework of InterPARES Project
}

\author{
Özgur Külcü*, Tolga Çakmak \\ Hacettepe University, Faculty of Letters, Department of Information Management, 06800 Beytepe, Ankara, Turkey
}

\section{A R T I C L E I N F O}

\section{Article history:}

Available online $\mathrm{xxx}$

\section{Keywords:}

Records management

Electronic records management

InterPARES Project

Archival management

Intuitional information management

\begin{abstract}
A B S T R A C T
Propose: In this study, existing conditions, problems, and expectations in the application of electronic records management in Turkey are evaluated on the basis of the data obtained from 17 institutions. The main goal of the study is to define to what extent the applications in information and records services in electronic environment are compatible with the expectations.

Design/methodology/approach: In this study, data were collected from surveys conducted in Turkey within the framework of the project InterPARES. Action research methodology was used in the study. The survey data were obtained from 17 institutions and results were evaluated in SPSS after their content analysis was conducted. The analysis was carried out in order to identify the conditions and problems in institutional electronic records management.

Findings: Problems in coordination of services, integration and independence of information systems, administrative arrangements, and lack of professional personnel were detected within the institutions, and it is seen that transition to the secure application of e-signature is of first priority.

Originality/value: This study contains analysis data about different institutions on ERM applications within the framework of an international project.
\end{abstract}

(C) 2009 Elsevier Ltd. All rights reserved.

\section{Objectives of the study}

Digital records and the applications that generate them have affected every aspect of business, research, government and domestic life. Several research projects worldwide have addressed these electronic records and their problems. One of the most comprehensive efforts has been made by the InterPARES (The International Research on Permanent Authentic Records in Electronic Systems) Project (1999-2006) on these issues. InterPARES is that such solutions are situation specific and must be devised by preservers in light of: (a) the cultural, legal, administrative, and functional context in which they operate; (b) the nature and characteristics of the organization or person producing the digital material; (c) the typology of the material produced and its documentary and technological features; (d) the limitations imposed by the available financial and human resources; (e) the organizational culture of both the producer of the material and the preserver itself (Duranti, 2007; InterPARES Project, 2008).

In light of this situation, the goal of Team Turkey in InterPARES 3 Project (2007-2012) is to enable Turkey's public and private

\footnotetext{
* Corresponding author. Tel.: +90 31229782 00; fax: +90 3122992014.

E-mail addresses: ozgurkulcu@gmail.com, kulcu@hacettepe.edu.tr (Ö. Külcü), tolgack@gmail.com, tcakmak@hacettepe.edu.tr (T. Çakmak).
}

archival organizations and programs, which are responsible for the digital records resulting from government, business, research, art and entertainment, social and/or community activities, to preserve over the long-term authentic records that satisfy the requirements of their stakeholders and society's needs for an adequate record of its past (InterPARES Project, 2008).

To achieve this goal, Team Turkey has identified the following objectives:

1. to assess the applicability of the recommendations of InterPARES and other projects about trusted record-making and recordkeeping to the situations of the small and medium sized archival organizations;

2. to assess the applicability of these projects' preservation solutions to the concrete cases identified by the test-bed;

3. to refine and further elaborate the theory and methods, concepts and principles developed by these research projects on the basis of the results of the above activities;

4. to establish when such theory and methods, concepts and principles apply across jurisdictions, regardless of legal/administrative, social and cultural environment (Duranti, 2007; InterPARES Project Organizational Policy, 2007).

In this study, existing conditions, problems, and expectations of the application of electronic records management in Turkey are 
evaluated on the basis of the data obtained from 17 institutions within the framework of the project InterPARES.

\section{Methodology}

These types of studies call for action research (McNiff \& Whitehead, 2006). Action research is a collection of participative and iterative methods, which pursue action (in this case, the preservation of digital records) and research at the same time. As a matter of course, action research forges collaborations between community members and researchers in a program of action and reflection toward positive change (Greenwood \& Levin, 2003). Action research makes extensive use of case study methodology and of direct communication and interaction with the subjects of the research, which are at the same time participants and contributors in the research activity (Duranti, 2007).

This study depends on findings acquired from the analysis carried out by the Turkish Team of InterPARES 3 Project. Contextual analysis, records, records keeping and policy analysis are based on the InterPARES 3 Project methodology. Each of the field surveys under the following titles was conducted in 17 different institutions and the required data were obtained.

1. Case study contextual analysis.

a. Institution, location, development, legal status, administrative structure, financial assistance, sources, management, constraints, aim and objectives.

b. Activities result in creation of records: administrative and managerial framework, general definition, types of activities, documents prepared during activities, existing records management program, personnel responsible for records procedures, strategies for records procedures, legal requirements and constraints, administrative requirements and constraints, ethical requirements and constraints.

2. Questions to be answered during Policy Case Studies (totally 18 defined questions).

3. Questions to be answered during Records Case Studies (totally 11 defined questions).

4. Questions to be answered during Records Keeping Case Studies (totally 14 defined questions) (InterPARES Project Organizational Policy, 2007).

\section{Development of records management in Turkey}

The basic regulation guiding records and archiving studies in Turkey is the "Law on Amended Decree Law on Disposing Redundant Records and Materials" released on October 04, 1988. "Regulation on State Archiving Services" of May 16, 1988, on the other hand, presents an application model for institutional records procedures. In addition to these regulations, various arrangements have been carried out in order to meet the requirements in records and archiving services within the framework of the changing conditions. It is thought that these arrangements have emerged for restructuring information and records procedures according to the changing conditions, coordinating these procedures with other related constituents, setting up the environment for realization of information and records procedures in electronic environment, and as a result of the process of alignment to the EU or similar international institutions. These arrangements are chronologically as follows:

1. "Receiving opinion of general directorate of state archives on sorting and disposing procedures, sending annual achieves activity report without delay, transfer of board of management or similar decisions and achieve material in old Turkish without delay to the state achieves". Prime Ministry Circular, No: 18975 October 20, 1998.

2. "Regulation on Amending the Regulation on State Archiving Services”. Republic of Turkey Official Journal, No: 24487, August 08, 2001: 95-100.

3. "Law on Freedom of Information". Republic of Turkey Official Journal, No: 25269, October 24, 2003: 1-8.

4. "Law on E-Signature". Republic of Turkey Official Journal, No: 25355, January 23, 2004: 1-8.

5. "Regulation on Principles and Procedures for Application of the Law on Right of Information". Republic of Turkey Official Journal, No: 25445, April 27, 2004: 1-13.

6. "Regulation on Principles and Procedures to be Applied in Official Correspondence". Republic of Turkey Official Journal, No: 25658, December 02, 2004: 5-26.

7. "Prime Ministry Circular on Standard File Plan". Republic of Turkey Prime Ministry General Directorate of Personnel and Principles, 320-3802, March 24, 2005: 1-55.

In addition to these arrangements, although not legalized yet, Draft Law on Foundation and Duties of General Directorate of State Achieves and State Archiving Services; and Draft Law on Organization for National Information Security and Its Duties have been finalized by Prime Ministry General Directorate of State Achieves (Elektronik, 2005, p. 88), and they have passed from the Commission of National Education in TGNA on May 04, 2006, which accelerated the legalization process (Reuters News Agency, 2006). This process is still in progress.

Not so long ago, Turkish Standards Institution published Turkish edition of ISO 15489, the international standard for records management (TS ISO 15489-1, 2007; TS ISO 15489-2, 2007). Another crucial study carried out in Turkey is Reference Model for System Criteria of Electronic Records Management (EBYSKRM) which was prepared in 2005 and whose revised second edition was published in 2006 (Kandur, 2006). Turkish Standards Institution adopted EBYSKRM as standard with the code of TSE 13298 on June 19, 2007 (Turkish Standards Institution). It is thought that TSE 13298 which was prepared compatible with the studies of ICA and Australian and British National Achieves, MoReq Model, DoD 5015.2 Standard, INTARPARES Project, ISO 15489 Standard, ANSI/ARMA Standards...., etc. would be beneficial in conducting studies on records management in electronic environment in Turkey which are compatible and coordinated with international applications and standards.

\section{Developments in the field of e-government and electronic records management}

The "E-Government Gate" portal which was opened on December 18 is regarded as the peak of successes in electronic public services and, in this framework, in electronic records management applications in Turkey. E-Government Gate is an Internet portal which provides access to all public services from a single point. The goal of the gate is summarized as offering public services to citizens, companies and public institutions through information and communication technologies in an effective and fruitful way (E-government gate, 2009).

Besides this general arrangement, many projects, application samples and arrangements in institutional basis, including erecords management and e-government applications, have been developed in Turkey. The major ones are chronologically shown below:

- Central Record Institution (CRI) of the Capital Markets Board ERM Project (Merkezi Kayıt Kuruluşu, 2008). 
- National Judicial Network Project (UYAP) (Adalet Bakanlığı, 2008).

- Central Population Management System (MERNIS) Project (Bilişim'07, 2007).

- Inward Processing Regime (DIR) Automation by the Undersecretariat of Foreign Trade of the Prime Ministry (Hatır, 2005; T.C. Başbakanlık Dış Ticaret Müsteşarlığı, 2008).

- Directorate General for the Protection of Citizens and Competition of the Ministry of Industry and Trade ERM Project (T.C. Sanayi ve Ticaret Bakanlığı, 2008).

- Turkish Patent Institution (TPE) ERM Project (Türk Patent Enstitüsü, 2007).

- The Ministry of Foreign Affairs ERM Applications (T.C. Dışişleri Bakanlığı, 2008).

- Social Security Administration ERM Insurance Project (T.C. Sosyal Güvenlik Kurumu, 2008).

- Directorate General of National Estate ERM Project (T.C. Maliye Bakanlığı Milli Emlak Genel Müdürlüğü, 2008).

- Undersecretariat of Customs ERM Project (T.C. Başbakanlık Gümrük Müsteşarlığı, 2008).

- Turkish Land Registry and Cadastre Information System (T.C. Bayındırlık ve İskân Bakanlığı Tapu ve Kadasro Genel Müdürlüğü, 2008).

- The Ministry of Agriculture Agricultural Database Project.

\section{Evaluation of electronic records management applications in Turkey: case study carried out in 17 institutions}

In the following part of the study, data obtained from case studies carried out in 17 different institutions in order to evaluate electronic records management applications in Turkey will be presented. The aim of these surveys is to identify the role of information and records management in institutional objectives, structure, functioning and practices of foundations which have diverse service activities; and to determine to what extend institutional information and records management activities are carried out in electronic environment.

The study, which was carried out to determine the dimension of electronic records management applications, includes data from case studies conducted in Turkey within the framework of the Project InterPARES. The case studies aiming to identify the institutional conditions and, in this framework, the electronic and printed information and records management expectations also prove to be the first in Turkey.

\section{Findings of surveys carried out in 17 institutions}

In this part of the study, findings from policy, records, contextual, and records keeping case studies which were carried out within the framework of InterPARES Methodology in 17 different institutions will be presented. The case studies which were designed to determine the conditions, problems and expectations in electronic records management in institutions enable a comprehensive assessment of situation. However, it was found necessary to digitize the data in order to evaluate and compare them, and results were evaluated in SPSS after their content analysis was conducted. Arithmetic mean and standard deviation of the data were also calculated in the fields which required Likert analysis. Since it was difficult to deal with each institution separately, they were divided into three groups and the evaluations were conducted considering the responses of these groups.

Table 1 includes the list of institutions in which analysis and survey studies were carried out. Analysis was conducted in the institutions using contextual, policy, records, and recordkeeping
Table 1

List of organizations.

\begin{tabular}{ll}
1 & Barlas Interior Design \\
2 & Ankara Province Board of Leagues \\
3 & Undersecretaries of the Prime Ministry for Foreign Trade \\
4 & Republic of Turkey, The Ministry of Public Works and Settlement: \\
5 & Hacettepe University Institute of Social Science \\
6 & Hacettepe University Adult Hospital \\
7 & Aselsan A.S. (Military Electronic Industry joint-stock company) \\
8 & Turkey Aerospace Industries Inc. \\
9 & Vehbi Koc Ankara Research Center \\
10 & Hacettepe University Library Department of Consultation and \\
11 & Hacettepe University Beytepe Center Library, User Service \\
12 & Middle East Technical University \\
13 & Atilim University Library \\
14 & ULAKBIM - Cahit Arf Information Center \\
15 & Adnan Otuken Public Library \\
16 & Turkey Radio and Television (TRT) Central Library \\
17 & Turkey Radio and Television (TRT) Istanbul Directorate \\
\hline
\end{tabular}

Table 2

Test-bed sectors.

\begin{tabular}{lrr}
\hline & $N$ & $\%$ \\
\hline Education\&Research & 6 & 35.3 \\
Service Sector & 5 & 29.4 \\
Governmental \& Military & 6 & 35.3 \\
Total & 17 & 100.0 \\
\hline
\end{tabular}

case study templates defined within the framework of InterPARES 3 methodology. Then, in order to obtain analytical results, these analysis data were assessed in accordance with contextual analysis technique and entered into SPSS (Statistical Package for the Social Sciences) which enabled to obtain the following results.

As it is shown in Table 2, the institutions in which research and analysis took place are divided into 3 groups as Education\&Research (35.3\%), Service Sector (29.4\%), and Governmental \& Military (35.3\%).

Fields of work in 17 institutions under 3 groups consist of information service, publishing, research, financial and governmental and medical information (Table 3 ).

In the study, analysis data was evaluated according to the groups listed in Table 2. There is information in Table 4 about how service policies are developed in the institutions. Education\&Research institutions are predominantly developing joint policies (50\%), while Governmental \& Military institutions realize in-house arrangements (83.3\%). Ratio of developing own service policy in units responsible for information and records procedures is under $21 \%$ in each three groups.

In each three groups, units which are responsible for information and records procedures have mostly no decision-making and expending power. Ratio of units having administrative and financial autonomy is under $30 \%$ in each three groups. $40 \%$ of institutions in service sector face problems in funds and support (Table 5).

Total number of personnel in units responsible for information and records procedures shows variation. The number of personnel in Education\&Research institutions is comparatively increasing. Service Sector and Governmental \& Military come after that (Table 6).

Table 3

Activity fields of the Institution.

\begin{tabular}{lrr}
\hline & $N$ & $\%$ \\
\hline Information Service & 6 & 35.3 \\
Publishing & 2 & 11.8 \\
Research & 4 & 23.5 \\
Financial and Governmental & 3 & 17.6 \\
Medical and Other Services & 2 & 11.8 \\
Total & 17 & 100.0 \\
\hline
\end{tabular}


Table 4

Collaborative efforts for policy making.

\begin{tabular}{lccccc}
\hline & & Individually & Organizationally & Inter-organizationally & Total \\
\hline Education\&Research & $N$ & 1 & 2 & 3 & 6 \\
\multirow{2}{*}{ Service Sector } & $\%$ & $16.7 \%$ & $33.3 \%$ & $50.0 \%$ & $100.0 \%$ \\
& $N$ & 1 & 2 & 2 & 5 \\
Governmental \& Military & $\%$ & $20.0 \%$ & $40.0 \%$ & $50.0 \%$ & 6 \\
& $N$ & 0 & $5 \%$ & 1 & $100.0 \%$ \\
Total & $\%$ & $83.3 \%$ & $9.7 \%$ & $100.0 \%$ \\
& $N$ & 2 & $92.9 \%$ & $35.3 \%$ & 17 \\
& $\%$ & $11.8 \%$ & & & $100.0 \%$ \\
\hline
\end{tabular}

Table 5

The management system and financial resources of the information and records system.

\begin{tabular}{|c|c|c|c|c|c|}
\hline & & $\begin{array}{l}\text { Independent } \\
\text { and sufficient }\end{array}$ & $\begin{array}{l}\text { Determined by } \\
\text { other units }\end{array}$ & $\begin{array}{l}\text { By legal deposit } \\
\text { law, gifts }\end{array}$ & Insufficient \\
\hline \multirow[t]{2}{*}{ Education\&Research } & $N$ & 2 & 6 & 1 & 0 \\
\hline & $\%$ & $33.3 \%$ & $100.0 \%$ & $16.7 \%$ & $0 \%$ \\
\hline \multirow[t]{2}{*}{ Service Sector } & $N$ & 2 & 3 & 1 & 2 \\
\hline & $\%$ & $40.0 \%$ & $60.0 \%$ & $20.0 \%$ & $40.0 \%$ \\
\hline \multirow[t]{2}{*}{ Governmental \& Military } & $N$ & 1 & 6 & 0 & 0 \\
\hline & $\%$ & $16.7 \%$ & $100.0 \%$ & $0 \%$ & $0 \%$ \\
\hline \multirow[t]{2}{*}{ Total } & $N$ & 5 & 15 & 2 & 2 \\
\hline & $\%$ & $29.4 \%$ & $88.2 \%$ & $11.8 \%$ & $11.8 \%$ \\
\hline
\end{tabular}

Table 6

Number of staff

\begin{tabular}{lcccccc}
\hline & & $1-3$ & $4-6$ & $7-10$ & $10-20$ & $20+$ \\
\hline Education\&Research & $N$ & 2 & 0 & 1 & 0 & 3 \\
& $\%$ & $33.3 \%$ & $0 \%$ & $16.7 \%$ & $0 \%$ & $50.0 \%$ \\
Service Sector & $N$ & 1 & 0 & 0 & 2 & 2 \\
& $\%$ & $20.0 \%$ & $0 \%$ & $0 \%$ & $40.0 \%$ & $40.0 \%$ \\
Governmental \& Military & $N$ & 3 & 1 & 1 & 0 & 1 \\
& $\%$ & $50.0 \%$ & $16.7 \%$ & $16.7 \%$ & $0 \%$ & $16.7 \%$ \\
Total & $N$ & 6 & 1 & 2 & 2 & 6 \\
& $\%$ & $35.3 \%$ & $5.9 \%$ & $11.8 \%$ & $11.8 \%$ & $35.3 \%$ \\
\hline
\end{tabular}

The number of personnel who were professionally trained for information and records services is significantly high. The most problematic group in trained personnel is Governmental \& Military (Table 7).

The highest ratio in annual records creation belongs to the group Service Sector ( $\left.\sum 2.6\right)$; it is followed by Education\&Research $\left(\sum 3\right)$ and Governmental \& Military $\left(\sum 2.3\right)$. Nevertheless, the personnel number of Service Sector is under that of Education\&Research as shown in the Table 6 . This shows that workload concerning records is heavier in Service Sector (Table 8).

Service Sector is the group in which existing policies and legal procedures on information and records management are most insufficient. Education\&Research group is comparatively in better condition, while Governmental \& Military group has an average result (Table 9 ).

Most of the institutions (more than 64\%) in each three groups asserted that they used records intensively in in-house transactions. Ratio of those who stated that they rarely used records in institutional transactions remained under $21 \%$ in each three groups (Table 10).

Though not so strong, each three groups have a system for conventional records (General $\sum 2.4$ ). In four institutions from Service and Education\&Research sectors, on the other hand, there are serious problems. In general, it is possible to say that the system for conventional records used in institutions serving in Governmental \& Military sector is better than others ( $\sum 2.0$ ) (Table 11).

While ratios of each three groups are not so strong on approaches of other units towards information and records procedures in the institution, there are still positive conditions (General $\sum 2.7$ ). Serious problems are observed in four institutions from Service Sector to Education\&Research. In the institutions serving in Education\&Research, in general, conditions seems slightly better than that of other groups ( $\sum 2.5$ ) (Table 12).

On average, $47.1 \%$ of the 17 institutions in which analysis and researches are conducted has a records manager trained on records management. This ratio increases up to $66.7 \%$ in Education\&Research group. The possibility of the personnel who is responsible for information and records procedures to be from other professions is under $21 \%$ in each three groups (Table 13 ).

Table 7

Professional qualifications of staff.

\begin{tabular}{|c|c|c|c|c|c|c|}
\hline & & All of them & Majority of them & Some of them & Insufficient Professional & $\sum$ \\
\hline \multirow[t]{2}{*}{ Education\&Research } & $N$ & 2 & 3 & 1 & 0 & 1.8 \\
\hline & $\%$ & $33.3 \%$ & $50.0 \%$ & $16.7 \%$ & $0 \%$ & \\
\hline \multirow[t]{2}{*}{ Service Sector } & $N$ & 0 & 2 & 1 & 2 & 3.0 \\
\hline & $\%$ & $0 \%$ & $40.0 \%$ & $20.0 \%$ & $40.0 \%$ & \\
\hline \multirow[t]{2}{*}{ Governmental \& Military } & $N$ & 1 & 0 & 2 & 3 & 3.1 \\
\hline & $\%$ & $16.7 \%$ & $0 \%$ & $33.3 \%$ & $50.0 \%$ & \\
\hline \multirow[t]{2}{*}{ Total } & $N$ & 3 & 5 & 4 & 5 & 2.6 \\
\hline & $\%$ & $17.6 \%$ & $29.4 \%$ & $23.5 \%$ & $29.4 \%$ & \\
\hline
\end{tabular}


Table 8

Number of records created each year.

\begin{tabular}{|c|c|c|c|c|c|c|c|c|}
\hline & & -4999 & $-20,000$ & $-50,000$ & $-100,000$ & $100,000+$ & Total & $\sum$ \\
\hline Education\&Research & $\begin{array}{l}N \\
\%\end{array}$ & $\begin{array}{c}2 \\
33.3 \%\end{array}$ & $\begin{array}{c}1 \\
16.7 \%\end{array}$ & $\begin{array}{c}1 \\
16.7 \%\end{array}$ & $\begin{array}{c}1 \\
16.7 \%\end{array}$ & $\begin{array}{c}1 \\
16.7 \%\end{array}$ & $\begin{array}{c}6 \\
100.0 \%\end{array}$ & 2.6 \\
\hline Service Sector & $\begin{array}{l}N \\
\%\end{array}$ & $\begin{array}{c}1 \\
20.0 \%\end{array}$ & $\begin{array}{c}2 \\
40.0 \%\end{array}$ & $\begin{array}{l}0 \\
0 \%\end{array}$ & $\begin{array}{l}0 \\
0 \%\end{array}$ & $\begin{array}{c}2 \\
40.0 \%\end{array}$ & $\begin{array}{c}5 \\
100.0 \%\end{array}$ & 3.0 \\
\hline Governmental \& Military & $\begin{array}{l}N \\
\%\end{array}$ & $\begin{array}{c}3 \\
50.0 \%\end{array}$ & $\begin{array}{l}0 \\
0 \%\end{array}$ & $\begin{array}{c}1 \\
16.7 \%\end{array}$ & $\begin{array}{c}2 \\
33.3 \%\end{array}$ & $\begin{array}{l}0 \\
0 \%\end{array}$ & $\begin{array}{c}6 \\
100.0 \%\end{array}$ & 2.3 \\
\hline Total & $\begin{array}{l}N \\
\%\end{array}$ & $\begin{array}{c}6 \\
35.3 \%\end{array}$ & $\begin{array}{c}3 \\
17.6 \%\end{array}$ & $\begin{array}{c}2 \\
11.8 \%\end{array}$ & $\begin{array}{c}3 \\
17.6 \%\end{array}$ & $\begin{array}{c}3 \\
17.6 \%\end{array}$ & $\begin{array}{c}17 \\
100.0 \%\end{array}$ & 2.6 \\
\hline
\end{tabular}

Table 9

Policies and legal procedures.

\begin{tabular}{|c|c|c|c|c|c|c|c|}
\hline & & TS & S & $\mathrm{U}$ & I & $\mathrm{TI}$ & \\
\hline \multirow[t]{2}{*}{ Education\&Research } & $N$ & 2 & 1 & 2 & 1 & 2 & 2.3 \\
\hline & $\%$ & $33.3 \%$ & $16.7 \%$ & $33.3 \%$ & $16.7 \%$ & $33.3 \%$ & \\
\hline \multirow[t]{2}{*}{ Service Sector } & $N$ & 0 & 1 & 3 & 1 & 0 & 3.0 \\
\hline & $\%$ & $0 \%$ & $20.0 \%$ & $60.0 \%$ & $20.0 \%$ & $0 \%$ & \\
\hline \multirow[t]{2}{*}{ Governmental \& Military } & $N$ & 1 & 2 & 2 & 1 & 1 & 2.5 \\
\hline & $\%$ & $16.7 \%$ & $33.3 \%$ & $33.3 \%$ & $16.7 \%$ & $16.7 \%$ & \\
\hline \multirow[t]{2}{*}{ Total } & $N$ & 3 & 4 & 7 & 3 & 3 & 2.5 \\
\hline & $\%$ & $17.6 \%$ & $23.5 \%$ & $41.2 \%$ & $17.6 \%$ & $17.6 \%$ & \\
\hline
\end{tabular}

TS: Totally Sufficient, S: Sufficient, U: Uncertain, I: Insufficient, TI: Totally Insufficient.

Table 10

Types of activities resulting from documents.

\begin{tabular}{lccccc}
\hline & & All & Majority & Some & Rare \\
\hline Education\&Research & $N$ & 1 & 5 & 0 & 0 \\
& $\%$ & $16.7 \%$ & $83.3 \%$ & $0 \%$ & $0 \%$ \\
Service Sector & $N$ & 1 & 3 & 0 & 1 \\
& $\%$ & $20.0 \%$ & $60.0 \%$ & $0 \%$ & $20.0 \%$ \\
Governmental \& Military & $N$ & 0 & 3 & 3 & 0 \\
& $\%$ & $0 \%$ & $50.0 \%$ & $50.0 \%$ & $0 \%$ \\
Total & $N$ & 2 & 11 & 3 & 1 \\
& $\%$ & $11.8 \%$ & $64.7 \%$ & $17.6 \%$ & $5.9 \%$ \\
\hline
\end{tabular}

A significant part (more than 79\%) of institutions in which analysis and researches were conducted creates or uses electronic records. Only two institutions out of 17 stated that they do not use electronic records in transactions (Table 14).

Six case educational institutions have a system for electronic records. However, with a serious ratio of $66.7 \%$, Governmental \& Military and $40 \%$ of Service Sector have not any system for electronic records (Table 15 ).

The reason for institutions to use electronic records is predominantly the administrative and controlling activities, while it is user statistics in Service Sector and providing source in Governmen- tal \& Military group. Education\&Research intensively uses the four variants in electronic records applications (Table 16).

The whole Education\&Research group and $80 \%$ of Service Sector possess software applications for information processing. 50\% of Governmental \& Military group have not any software for institutional information systems (Table 17).

Software applications for information systems in Education\&Research group, include, in general, the whole acquisition, browsing, intuitional transactions and public relations modules. The module on acquisition of information and records sources exists in only one institution. In Governmental \& Military sector, no institutions have software application for institutional transactions. In the same group, only one foundation has public relation module (Table 18).

On average, $35.3 \%$ of the case institutions have an integrated and identified records management system which is composed of functions from creation to disposition. It is seen that disposition module of the program is inefficient in Education\&Research (16.7\%) and in Service Sector (20\%). In Governmental \& Military group, apart from the data on information systems, records management systems are more comprehensive than that of other groups (Table 19).

In Governmental \& Military group, identifying ratio of records creation in ERM applications was found to be higher than other groups. In all groups, ratio of inclusion of disposition in ERM is under

Table 11

Does the archives have a strong record/archives policy for traditional records?.

\begin{tabular}{|c|c|c|c|c|c|c|c|}
\hline & & Strongly agree & Agree & Neutral & Disagree & $\sum$ & S.D. \\
\hline \multirow[t]{2}{*}{ Education\&Research } & $N$ & 2 & 0 & 2 & 2 & 2.6 & .55 \\
\hline & $\%$ & $33.3 \%$ & $0 \%$ & $33.3 \%$ & $33.3 \%$ & & \\
\hline \multirow[t]{2}{*}{ Service Sector } & $N$ & 2 & 0 & 1 & 2 & 2.6 & .67 \\
\hline & $\%$ & $40.0 \%$ & $0 \%$ & $20.0 \%$ & $40.0 \%$ & & \\
\hline \multirow[t]{2}{*}{ Governmental \& Military } & $N$ & 2 & 2 & 2 & 0 & 2.0 & .36 \\
\hline & $\%$ & $33.3 \%$ & $33.3 \%$ & $33.3 \%$ & $0 \%$ & & \\
\hline \multirow[t]{2}{*}{ Total } & $N$ & 6 & 2 & 5 & 4 & 2.4 & 1.2 \\
\hline & $\%$ & $35.3 \%$ & $11.8 \%$ & $29.4 \%$ & $23.5 \%$ & & \\
\hline
\end{tabular}


Table 12

Are the procedures enough for ensuring that all the concerned parties are aware of, comprehend and apply the records/archives policy.

\begin{tabular}{lcccccc}
\hline & & Agree & Neutral & Disagree & $\sum$ & S.D. \\
\hline Education\&Research & $N$ & 3 & 3 & 0 & & \\
\multirow{3}{*}{ Service Sector } & $\%$ & $50.0 \%$ & $50.0 \%$ & $0 \%$ & 2.5 & .22 \\
& $N$ & 3 & 0 & 2 & & \\
Governmental \& Military & $\%$ & $60.0 \%$ & $0 \%$ & $40.0 \%$ & 2.8 & .49 \\
& $\%$ & 2 & 3 & 1 & & \\
Total & $\%$ & $33.3 \%$ & $50.0 \%$ & $16.7 \%$ & 2.8 & .30 \\
& $N$ & 8 & 6 & 3 & & \\
& $\%$ & $47.1 \%$ & $35.3 \%$ & $17.6 \%$ & 2.7 & .77 \\
\hline
\end{tabular}

Table 13

The responsibility for the records/archives issues.

\begin{tabular}{lcccc}
\hline & & $\begin{array}{l}\text { Record } \\
\text { manager }\end{array}$ & $\begin{array}{c}\text { Information } \\
\text { manager }\end{array}$ & $\begin{array}{c}\text { General } \\
\text { manager }\end{array}$ \\
\hline Education\&Research & $N$ & 4 & 1 & 1 \\
& $\%$ & $66.7 \%$ & $16.7 \%$ & $16.7 \%$ \\
Service Sector & $N$ & 1 & 3 & 1 \\
& $\%$ & $20.0 \%$ & $60.0 \%$ & $20.0 \%$ \\
Governmental \& Military & & & & \\
& $N$ & 3 & 2 & 1 \\
Total & $\%$ & $50.0 \%$ & $33.3 \%$ & $16.7 \%$ \\
& $N$ & 8 & 6 & 3 \\
& $\%$ & $47.1 \%$ & $35.3 \%$ & $17.6 \%$ \\
\hline
\end{tabular}

Table 14

Electronic record creation.

\begin{tabular}{lccc}
\hline & & Yes & No \\
\hline Education\&Research & $N$ & 6 & 0 \\
\multirow{2}{*}{ Service Sector } & $\%$ & $100.0 \%$ & $.0 \%$ \\
& $N$ & 4 & 1 \\
Governmental \& Military & $\%$ & $80.0 \%$ & $20.0 \%$ \\
& $N$ & 5 & 1 \\
Total & $\%$ & $83.3 \%$ & $16.7 \%$ \\
& $N$ & 15 & 2 \\
& $\%$ & $88.2 \%$ & $11.8 \%$ \\
\hline
\end{tabular}

Table 15

Electronic record system usage.

\begin{tabular}{lccc}
\hline & & Majority & Some \\
\hline Education\&Research & $N$ & 6 & 0 \\
\multirow{2}{*}{ Service Sector } & $\%$ & $100.0 \%$ & $0 \%$ \\
& $N$ & 3 & 2 \\
Governmental \& Military & $\%$ & $60.0 \%$ & $40.0 \%$ \\
& $N$ & 2 & 4 \\
Total & $\%$ & $33.3 \%$ & $66.7 \%$ \\
& $N$ & 11 & 6 \\
& $\%$ & $64.7 \%$ & $35.3 \%$ \\
\hline
\end{tabular}

Table 17

Information system software usage.

\begin{tabular}{lccc}
\hline & & Yes & No \\
\hline Education\&Research & $N$ & 6 & 0 \\
\multirow{2}{*}{ Service Sector } & $\%$ & $100.0 \%$ & $0 \%$ \\
& $N$ & 4 & 1 \\
Governmental \& Military & $\%$ & $80.0 \%$ & $20.0 \%$ \\
& $N$ & 3 & 3 \\
Total & $\%$ & $50.0 \%$ & $50.0 \%$ \\
& $N$ & 13 & 4 \\
& $\%$ & $76.5 \%$ & $23.5 \%$ \\
\hline
\end{tabular}

21\%. In Service Sector, the predominant application for dissemination of records is based on manual systems. Institutions mostly use electronic systems in filing applications (Totally 76.5\%) (Table 20).

Sufficiency ratio of technological infrastructure for electronic records in the institutions is under $50 \%$ in each three groups. It is striking that infrastructure facilities of $33.3 \%$ of Governmental \& Military group and $20 \%$ of Service Sector were defined as totally insufficient (Table 21).

Intended users of digital records in Education\&Research group are researchers (66.7\%). There is a balanced distribution to all fields in Service Sector, while in Governmental \& Military group the target group substantially consists of workers of institutions (83.3\%) (Table 22).

While identifying data within ERM applied by institutions, the following items take part in sequence: title (totally 100\%), date (94.1\%), code data (64.7\%), related activities (35.3\%) and summary (35.3\%). Absence of some identified metadata can be regarded as an inadequacy (Table 23).

In each three groups, official applications (correspondences, directives, forms, etc.) and databases take part within electronic recordkeeping system as a whole. While recordkeeping does not include e-mails in Service Sector, tracking files are kept in electronic environment in only one institution in Governmental \& Military group (Table 24).

The following five successive components are designed to determine the measures of the creator enough to ensure the accuracy, reliability and authenticity of the digital records and their documentation in the institutions within the framework of InterPARES methodology.

It is stated that the existing systems for authorization of records were strong in each three groups (Arithmetic mean of responses is low, while support to the argument that the system is strong) (General $\sum 1.88$ ). The records system for authorization is strongest in Education\&Research group ( $\left.\sum 1.67\right)$. In Governmental \& Military group, on the other hand, the responses are in mean values ( $\left.\sum 2.17\right)$. It is stated that there was $16.7 \%$ of authorization problem in Governmental \& Military group, which proves to be an important fact (Table 25).

\section{Table 16}

The reasons for using electronic records.

\begin{tabular}{|c|c|c|c|c|c|}
\hline & & User statistics & Resource acquisition & Managerial works & Management and control \\
\hline \multirow[t]{2}{*}{ Education\&Research } & $N$ & 5 & 5 & 3 & 6 \\
\hline & $\%$ & $83.3 \%$ & $83.3 \%$ & $50.0 \%$ & $100.0 \%$ \\
\hline \multirow[t]{2}{*}{ Service Sector } & $N$ & 5 & 1 & 2 & 5 \\
\hline & $\%$ & $100.0 \%$ & $20.0 \%$ & $40.0 \%$ & $100.0 \%$ \\
\hline \multirow[t]{2}{*}{ Governmental \& Military } & $N$ & 1 & 4 & 6 & 5 \\
\hline & $\%$ & $16.7 \%$ & $66.7 \%$ & $100.0 \%$ & $83.3 \%$ \\
\hline \multirow[t]{2}{*}{ Total } & $N$ & 11 & 10 & 11 & 16 \\
\hline & $\%$ & $64.7 \%$ & $58.8 \%$ & $64.7 \%$ & $94.1 \%$ \\
\hline
\end{tabular}


Table 18

The Scope of the information system software.

\begin{tabular}{|c|c|c|c|c|c|c|}
\hline & & Acquisition & Browsing & Lending & Transaction & Public Relations \\
\hline Education\&Research & $\begin{array}{l}N \\
\%\end{array}$ & $\begin{array}{c}3 \\
50.0 \%\end{array}$ & $\begin{array}{c}6 \\
100.0 \%\end{array}$ & $\begin{array}{c}4 \\
66.7 \%\end{array}$ & $\begin{array}{c}4 \\
66.7 \%\end{array}$ & $\begin{array}{c}3 \\
50.0 \%\end{array}$ \\
\hline Service Sector & $\begin{array}{l}N \\
\%\end{array}$ & $\begin{array}{c}1 \\
20.0 \%\end{array}$ & $\begin{array}{c}4 \\
80.0 \%\end{array}$ & $\begin{array}{c}2 \\
40.0 \%\end{array}$ & $\begin{array}{c}3 \\
60.0 \%\end{array}$ & $\begin{array}{c}4 \\
80.0 \%\end{array}$ \\
\hline Governmental \& Military & $\begin{array}{l}N \\
\%\end{array}$ & $\begin{array}{c}2 \\
33.3 \%\end{array}$ & $\begin{array}{c}3 \\
50.0 \%\end{array}$ & $\begin{array}{c}3 \\
50.0 \%\end{array}$ & $\begin{array}{l}0 \\
0 \%\end{array}$ & $\begin{array}{c}1 \\
16.7 \%\end{array}$ \\
\hline Total & $\begin{array}{l}N \\
\%\end{array}$ & $\begin{array}{c}6 \\
35.3 \%\end{array}$ & $\begin{array}{l}13 \\
76.5 \%\end{array}$ & $\begin{array}{c}9 \\
52.9 \%\end{array}$ & $\begin{array}{c}7 \\
41.2 \%\end{array}$ & $\begin{array}{c}8 \\
47.1 \%\end{array}$ \\
\hline
\end{tabular}

Table 19

Organizational record management program.

\begin{tabular}{|c|c|c|c|c|c|c|}
\hline & & Creation & Filing/Distribution & Retention & Disposition & All \\
\hline \multirow[t]{2}{*}{ Education\&Research } & $N$ & 6 & 5 & 3 & 1 & 1 \\
\hline & $\%$ & $100.0 \%$ & $83.3 \%$ & $50.0 \%$ & $16.7 \%$ & $16.7 \%$ \\
\hline \multirow[t]{2}{*}{ Service Sector } & $N$ & 3 & 3 & 4 & 1 & 1 \\
\hline & $\%$ & $60.0 \%$ & $60.0 \%$ & $80.0 \%$ & $20.0 \%$ & $20.0 \%$ \\
\hline \multirow[t]{2}{*}{ Governmental \& Military } & $N$ & 4 & 6 & 5 & 4 & 4 \\
\hline & $\%$ & $66.7 \%$ & $100.0 \%$ & $83.3 \%$ & $66.7 \%$ & $66.7 \%$ \\
\hline \multirow[t]{2}{*}{ Total } & $N$ & 13 & 14 & 12 & 6 & 6 \\
\hline & $\%$ & $76.5 \%$ & $82.4 \%$ & $70.6 \%$ & $35.3 \%$ & $35.3 \%$ \\
\hline
\end{tabular}

Table 20

Electronic records management program in life cycle.

\begin{tabular}{|c|c|c|c|c|c|c|}
\hline & & Creation & Filing & Distribution & Retention & Disposition \\
\hline Education\&Research & $\begin{array}{l}N \\
\%\end{array}$ & $\begin{array}{c}5 \\
83.3 \%\end{array}$ & $\begin{array}{c}5 \\
83.3 \%\end{array}$ & $\begin{array}{c}4 \\
66.7 \%\end{array}$ & $\begin{array}{c}3 \\
50.0 \%\end{array}$ & $\begin{array}{c}1 \\
16.7 \%\end{array}$ \\
\hline Service Sector & $\begin{array}{l}N \\
\%\end{array}$ & $\begin{array}{c}4 \\
80.0 \%\end{array}$ & $\begin{array}{c}3 \\
60.0 \%\end{array}$ & $\begin{array}{c}2 \\
40.0 \%\end{array}$ & $\begin{array}{c}4 \\
80.0 \%\end{array}$ & $\begin{array}{c}1 \\
20.0 \%\end{array}$ \\
\hline Governmental \& Military & $\begin{array}{l}N \\
\%\end{array}$ & $\begin{array}{c}2 \\
33.3 \%\end{array}$ & $\begin{array}{c}5 \\
83.3 \%\end{array}$ & $\begin{array}{c}4 \\
66.7 \%\end{array}$ & $\begin{array}{c}3 \\
50.0 \%\end{array}$ & $\begin{array}{c}1 \\
16.7 \%\end{array}$ \\
\hline Total & $\begin{array}{l}N \\
\%\end{array}$ & $\begin{array}{l}11 \\
64.7 \%\end{array}$ & $\begin{array}{l}13 \\
76.5 \%\end{array}$ & $\begin{array}{l}10 \\
58.8 \%\end{array}$ & $\begin{array}{l}10 \\
58.8 \%\end{array}$ & $\begin{array}{c}3 \\
17.6 \%\end{array}$ \\
\hline
\end{tabular}

Table 21

Technologic infrastructure for electronic records.

\begin{tabular}{|c|c|c|c|c|c|c|c|}
\hline & & Totally sufficient & Uncertain & Insufficient & Totally insufficient & $\sum$ & S.D. \\
\hline \multirow[t]{2}{*}{ Education\&Research } & $N$ & 2 & 1 & 3 & 0 & & \\
\hline & $\%$ & $33.3 \%$ & $16.7 \%$ & $50.0 \%$ & $0 \%$ & 2.1 & .983 \\
\hline \multirow[t]{2}{*}{ Service Sector } & $N$ & 1 & 1 & 2 & 1 & & \\
\hline & $\%$ & $20.0 \%$ & $20.0 \%$ & $40.0 \%$ & $20.0 \%$ & 2.6 & 1.14 \\
\hline \multirow[t]{2}{*}{ Governmental \& Military } & $N$ & 2 & 1 & 1 & 2 & & \\
\hline & $\%$ & $33.3 \%$ & $16.7 \%$ & $16.7 \%$ & $33.3 \%$ & 2.5 & 1.37 \\
\hline \multirow[t]{2}{*}{ Total } & $N$ & 5 & 3 & 6 & 3 & & \\
\hline & $\%$ & $29.4 \%$ & $17.6 \%$ & $35.3 \%$ & $17.6 \%$ & 2.4 & 1.12 \\
\hline
\end{tabular}

Table 22

Intended users of digital records.

\begin{tabular}{|c|c|c|c|c|c|}
\hline & & All Public & Researchers & Staff & Authorized staff \\
\hline \multirow[t]{2}{*}{ Education\&Research } & $N$ & 2 & 4 & 0 & 0 \\
\hline & $\%$ & $33.3 \%$ & $66.7 \%$ & $0 \%$ & $0 \%$ \\
\hline \multirow[t]{2}{*}{ Service Sector } & $N$ & 2 & 1 & 2 & 0 \\
\hline & $\%$ & $40.0 \%$ & $20.0 \%$ & $40.0 \%$ & $0 \%$ \\
\hline \multirow[t]{2}{*}{ Governmental \& Military } & $N$ & 0 & 0 & 5 & 1 \\
\hline & $\%$ & $0 \%$ & $0 \%$ & $83.3 \%$ & $16.7 \%$ \\
\hline \multirow[t]{2}{*}{ Total } & $N$ & 4 & 5 & 7 & 1 \\
\hline & $\%$ & $23.5 \%$ & $29.4 \%$ & $41.2 \%$ & $5.9 \%$ \\
\hline
\end{tabular}


Table 23

Metadata which is manually added to the records by their author and their creator.

\begin{tabular}{|c|c|c|c|c|c|c|}
\hline & & Title & Date & Related activity & Summary & Codes \\
\hline Education\&Research & $\begin{array}{l}N \\
\%\end{array}$ & $\begin{array}{c}6 \\
100.0 \%\end{array}$ & $\begin{array}{c}5 \\
83.3 \%\end{array}$ & $\begin{array}{c}2 \\
33.3 \%\end{array}$ & $\begin{array}{c}3 \\
50.0 \%\end{array}$ & $\begin{array}{c}4 \\
66.7 \%\end{array}$ \\
\hline Service Sector & $\begin{array}{l}N \\
\%\end{array}$ & $\begin{array}{c}5 \\
100.0 \%\end{array}$ & $\begin{array}{c}5 \\
100.0 \%\end{array}$ & $\begin{array}{c}3 \\
60.0 \%\end{array}$ & $\begin{array}{c}2 \\
40.0 \%\end{array}$ & $\begin{array}{c}4 \\
80.0 \%\end{array}$ \\
\hline Governmental \& Military & $\begin{array}{l}N \\
\%\end{array}$ & $\begin{array}{c}6 \\
100.0 \%\end{array}$ & $\begin{array}{c}6 \\
100.0 \%\end{array}$ & $\begin{array}{c}1 \\
16.7 \%\end{array}$ & $\begin{array}{c}1 \\
16.7 \%\end{array}$ & $\begin{array}{c}3 \\
50.0 \%\end{array}$ \\
\hline Total & & $\begin{array}{c}17 \\
100.0 \%\end{array}$ & $\begin{array}{l}16 \\
94.1 \%\end{array}$ & $\begin{array}{c}6 \\
35.3 \%\end{array}$ & $\begin{array}{c}6 \\
35.3 \%\end{array}$ & $\begin{array}{l}11 \\
64.7 \%\end{array}$ \\
\hline
\end{tabular}

\section{Table 24}

Electronic recordkeeping system.

\begin{tabular}{|c|c|c|c|c|c|c|}
\hline & & E-mail & Tracking & Work Flow & Office & Databases \\
\hline \multirow[t]{2}{*}{ Education\&Research } & $N$ & 2 & 3 & 3 & 6 & 6 \\
\hline & $\%$ & $33.3 \%$ & $50.0 \%$ & $50.0 \%$ & $100.0 \%$ & $100.0 \%$ \\
\hline \multirow[t]{2}{*}{ Service Sector } & $N$ & 0 & 2 & 3 & 5 & 5 \\
\hline & $\%$ & $0 \%$ & $40.0 \%$ & $60.0 \%$ & $100.0 \%$ & $100.0 \%$ \\
\hline \multirow[t]{2}{*}{ Governmental \& Military } & $N$ & 2 & 1 & 2 & 6 & 6 \\
\hline & $\%$ & $33.3 \%$ & $16.7 \%$ & $33.3 \%$ & $100.0 \%$ & $100.0 \%$ \\
\hline
\end{tabular}

Table 25

Authorization.

\begin{tabular}{|c|c|c|c|c|c|c|c|}
\hline & & Strongly agree & Agree & $\mathrm{N} / \mathrm{A}$ & Disagree & $\sum$ & S.D. \\
\hline \multirow[t]{2}{*}{ Education\&Research } & $N$ & 3 & 2 & 1 & 0 & & \\
\hline & $\%$ & $50.0 \%$ & $33.3 \%$ & $16.7 \%$ & $0 \%$ & 1.67 & .333 \\
\hline \multirow[t]{2}{*}{ Service Sector } & $N$ & 2 & 2 & 1 & 0 & & \\
\hline & $\%$ & $40.0 \%$ & $40.0 \%$ & $20.0 \%$ & $0 \%$ & 1.80 & .374 \\
\hline \multirow[t]{2}{*}{ Governmental \& Military } & $N$ & 3 & 0 & 2 & 1 & & \\
\hline & $\%$ & $50.0 \%$ & $0 \%$ & $33.3 \%$ & $16.7 \%$ & 2.17 & .543 \\
\hline \multirow[t]{2}{*}{ Total } & $N$ & 8 & 4 & 4 & 1 & & \\
\hline & $\%$ & $47.1 \%$ & $23.5 \%$ & $23.5 \%$ & $5.9 \%$ & 1.88 & .993 \\
\hline
\end{tabular}

It is seen that there is no problem in security systems of ERM applications (General $\sum 1.59$ ). Only in one institution, there are uncertainties about system in Education\&Research (Table 26).

There is also no problem in backup applications within the scope of ERM in the institutions. Except for the uncertainties in $16.7 \%$ of the Education\&Research group, smooth functioning of the system is confirmed by responses "agree" and "strongly agree" (Table 27).

The most problematic field in ERM applications is thought to be digital signature. In this context, none of the 17 institutions responded positively. The height of arithmetic mean values support this result (General $\sum 4.24$ ) (Table 28).

No serious problem was observed in long-term preservation of records within ERM except for one institution from Education\&Research group. Nevertheless, some uncertainties on long-term preservation in $40 \%$ of Service Sector and $33.3 \%$ of Education\&Research group have been observed (Table 29).

The most common applications within preservation methods of digital records are information system in and receiving backup for Education\&Research, receiving hard copy and backup for Service Sector, and receiving hard copy for Governmental \& Military group. $50 \%$ of institutions in Governmental \& Military group expressed that they did not receive backup, which proves to be an important fact (Table 30).

The case institutions mostly make use of changes in records which are stored in electronic systems for updating (totally $82.4 \%$ ) and deleting (82.4\%). Also, adding new information to records (70.6\%) and making changes on records (64.7\%) are processes that are frequently carried out. Adding new information to records, making changes on them or deleting them needs to be conducted

\section{Table 26}

Security system.

\begin{tabular}{|c|c|c|c|c|c|c|}
\hline & & Strongly agree & Agree & $\mathrm{N} / \mathrm{A}$ & $\sum$ & S.D. \\
\hline Education\&Research & $\begin{array}{l}N \\
\%\end{array}$ & $\begin{array}{c}3 \\
50.0 \%\end{array}$ & $\begin{array}{c}2 \\
33.3 \%\end{array}$ & $\begin{array}{c}1 \\
16.7 \%\end{array}$ & 1.67 & .816 \\
\hline Service Sector & $\begin{array}{l}N \\
\%\end{array}$ & $\begin{array}{c}2 \\
40.0 \%\end{array}$ & $\begin{array}{c}3 \\
60.0 \%\end{array}$ & $\begin{array}{l}0 \\
0 \%\end{array}$ & 1.60 & .548 \\
\hline Governmental \& Military & $\begin{array}{l}N \\
\%\end{array}$ & $\begin{array}{c}3 \\
50.0 \%\end{array}$ & $\begin{array}{c}3 \\
50.0 \%\end{array}$ & $\begin{array}{l}0 \\
0 \%\end{array}$ & 1.50 & .548 \\
\hline
\end{tabular}


Table 27

Backup.

\begin{tabular}{|c|c|c|c|c|c|c|}
\hline & & Strongly agree & Agree & $\mathrm{N} / \mathrm{A}$ & $\sum$ & S.D. \\
\hline \multirow[t]{2}{*}{ Education\&Research } & $N$ & 2 & 3 & 1 & & \\
\hline & $\%$ & $33.3 \%$ & $50.0 \%$ & $16.7 \%$ & 1.83 & .753 \\
\hline \multirow[t]{2}{*}{ Service Sector } & $N$ & 2 & 3 & 0 & & \\
\hline & $\%$ & $40.0 \%$ & $60.0 \%$ & $0 \%$ & 1.60 & .548 \\
\hline \multirow[t]{2}{*}{ Governmental \& Military } & $N$ & 3 & 3 & 0 & & \\
\hline & $\%$ & $50.0 \%$ & $50.0 \%$ & $0 \%$ & 1.50 & .548 \\
\hline \multirow[t]{2}{*}{ Total } & $N$ & 7 & 9 & 1 & & \\
\hline & $\%$ & $41.2 \%$ & $52.9 \%$ & $5.9 \%$ & 1.65 & .606 \\
\hline
\end{tabular}

Table 28

Digital signature.

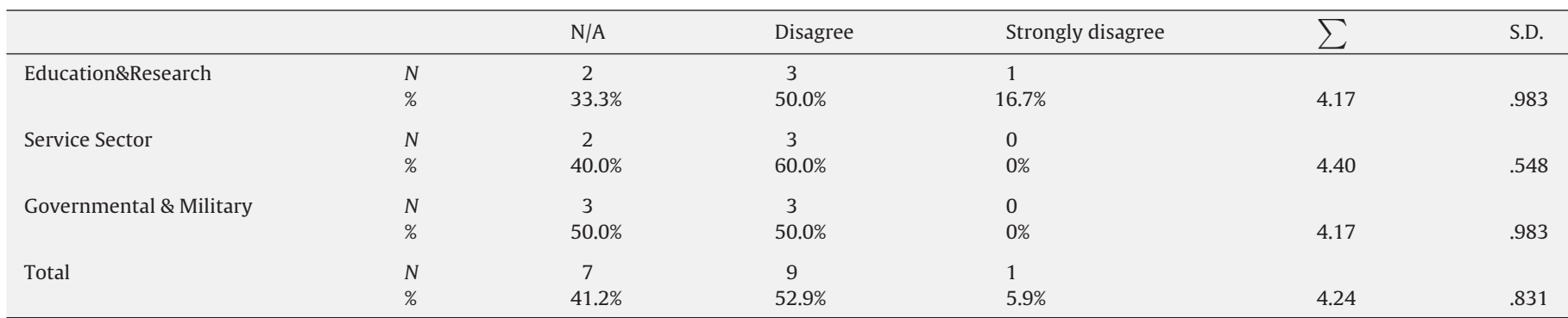

Table 29

Long-term preservation.

\begin{tabular}{|c|c|c|c|c|c|c|c|}
\hline & & Strongly agree & Agree & $\mathrm{N} / \mathrm{A}$ & Disagree & $\sum$ & S.D. \\
\hline \multirow[t]{2}{*}{ Education\&Research } & $N$ & 2 & 1 & 2 & 1 & & \\
\hline & $\%$ & $33.3 \%$ & $16.7 \%$ & $33.3 \%$ & $16.7 \%$ & 2.33 & 1.211 \\
\hline \multirow[t]{2}{*}{ Service Sector } & $N$ & 1 & 2 & 2 & 0 & & \\
\hline & $\%$ & $20.0 \%$ & $40.0 \%$ & $40.0 \%$ & $0 \%$ & 2.20 & .837 \\
\hline \multirow[t]{2}{*}{ Governmental \& Military } & $N$ & 4 & 2 & 0 & 0 & & \\
\hline & $\%$ & $66.7 \%$ & $33.3 \%$ & $0 \%$ & $0 \%$ & 1.33 & .516 \\
\hline \multirow[t]{2}{*}{ Total } & $N$ & 7 & 5 & 4 & 1 & & \\
\hline & $\%$ & $41.2 \%$ & $29.4 \%$ & $23.5 \%$ & $5.9 \%$ & 1.94 & .966 \\
\hline
\end{tabular}

Table 30

Preservation methods of the digital records.

\begin{tabular}{|c|c|c|c|c|c|}
\hline & & Creator's desktop & Information system & Printed & Backup \\
\hline Education\&Research & $\begin{array}{l}N \\
\%\end{array}$ & $\begin{array}{c}3 \\
50.0 \%\end{array}$ & $\begin{array}{c}6 \\
100.0 \%\end{array}$ & $\begin{array}{c}4 \\
66.7 \%\end{array}$ & $\begin{array}{c}6 \\
100.0 \%\end{array}$ \\
\hline Service Sector & $\begin{array}{l}N \\
\%\end{array}$ & $\begin{array}{c}1 \\
20.0 \%\end{array}$ & $\begin{array}{c}4 \\
80.0 \%\end{array}$ & $\begin{array}{c}5 \\
100.0 \%\end{array}$ & $\begin{array}{c}5 \\
100.0 \%\end{array}$ \\
\hline Governmental \& Military & $\begin{array}{l}N \\
\%\end{array}$ & $\begin{array}{c}3 \\
50.0 \%\end{array}$ & $\begin{array}{c}4 \\
66.7 \%\end{array}$ & $\begin{array}{c}5 \\
83.3 \%\end{array}$ & $\begin{array}{c}3 \\
50.0 \%\end{array}$ \\
\hline Total & $\begin{array}{l}N \\
\%\end{array}$ & $\begin{array}{c}7 \\
41.2 \%\end{array}$ & $\begin{array}{l}14 \\
82.4 \%\end{array}$ & $\begin{array}{l}14 \\
82.4 \%\end{array}$ & $\begin{array}{l}14 \\
82.4 \%\end{array}$ \\
\hline
\end{tabular}

Table 31

Changes on digital records.

\begin{tabular}{|c|c|c|c|c|c|c|}
\hline & & Updating & Adding & Deleting & Recoding & Changing \\
\hline \multirow[t]{2}{*}{ Education\&Research } & $N$ & 6 & 5 & 4 & 3 & 6 \\
\hline & $\%$ & $100.0 \%$ & $83.3 \%$ & $66.7 \%$ & $50.0 \%$ & $100.0 \%$ \\
\hline \multirow[t]{2}{*}{ Service Sector } & $N$ & 4 & 4 & 5 & 2 & 3 \\
\hline & $\%$ & $80.0 \%$ & $80.0 \%$ & $100.0 \%$ & $40.0 \%$ & $60.0 \%$ \\
\hline \multirow[t]{2}{*}{ Governmental \& Military } & $N$ & 4 & 3 & 5 & 1 & 2 \\
\hline & $\%$ & $66.7 \%$ & $50.0 \%$ & $83.3 \%$ & $16.7 \%$ & $33.3 \%$ \\
\hline \multirow[t]{2}{*}{ Total } & $N$ & 14 & 12 & 14 & 6 & 11 \\
\hline & $\%$ & $82.4 \%$ & $70.6 \%$ & $82.4 \%$ & $35.3 \%$ & $64.7 \%$ \\
\hline
\end{tabular}


Table 32

Are there a sufficient relationship between units that are involved with records/archives creation and management?

\begin{tabular}{|c|c|c|c|c|c|c|c|}
\hline & & Strongly agree & Agree & $\mathrm{N} / \mathrm{A}$ & Disagree & $\sum$ & S.D. \\
\hline \multirow[t]{2}{*}{ Education\&Research } & $N$ & 3 & 1 & 0 & 2 & & \\
\hline & $\%$ & $50.0 \%$ & $16.7 \%$ & $0 \%$ & $33.3 \%$ & 2.17 & 1.472 \\
\hline \multirow[t]{2}{*}{ Service Sector } & $N$ & 2 & 1 & 2 & 0 & & \\
\hline & $\%$ & $40.0 \%$ & $20.0 \%$ & $40.0 \%$ & $0 \%$ & 2.00 & 1.00 \\
\hline \multirow[t]{2}{*}{ Governmental \& Military } & $N$ & 1 & 1 & 3 & 1 & & \\
\hline & $\%$ & $16.7 \%$ & $16.7 \%$ & $50.0 \%$ & $16.7 \%$ & 2.67 & 1.33 \\
\hline \multirow[t]{2}{*}{ Total } & $N$ & 6 & 3 & 5 & 3 & & \\
\hline & $\%$ & $35.3 \%$ & $17.6 \%$ & $29.4 \%$ & $17.6 \%$ & 2.29 & 1.160 \\
\hline
\end{tabular}

Table 33

The relationship between records to the archival bonds or other media.

\begin{tabular}{|c|c|c|c|c|c|}
\hline & & Separated & Coordinated with indoor & Integrated with indoor & Integrated with other Inst. \\
\hline \multirow[t]{2}{*}{ Education\&Research } & $N$ & 3 & 2 & 1 & 0 \\
\hline & $\%$ & $50.0 \%$ & $33.3 \%$ & $16.7 \%$ & $0 \%$ \\
\hline \multirow[t]{2}{*}{ Service Sector } & $N$ & 0 & 4 & 1 & 0 \\
\hline & $\%$ & $0 \%$ & $80.0 \%$ & $20.0 \%$ & $0 \%$ \\
\hline \multirow[t]{2}{*}{ Governmental \& Military } & $N$ & 3 & 3 & 0 & 0 \\
\hline & $\%$ & $50.0 \%$ & $50.0 \%$ & $0 \%$ & $0 \%$ \\
\hline \multirow[t]{2}{*}{ Total } & $N$ & 6 & 9 & 2 & 0 \\
\hline & $\%$ & $35.3 \%$ & $52.9 \%$ & $11.8 \%$ & $0 \%$ \\
\hline
\end{tabular}

Table 34

If the archives has the records in custody, how were they acquired? How were they processed?

\begin{tabular}{|c|c|c|c|c|c|c|}
\hline & & Classification & Filing & Retention plans & Purchasing/gifting & Other \\
\hline \multirow[t]{2}{*}{ Education\&Research } & $N$ & 4 & 4 & 0 & 3 & 2 \\
\hline & $\%$ & $66.7 \%$ & $66.7 \%$ & $0 \%$ & $50.0 \%$ & $33.3 \%$ \\
\hline \multirow[t]{2}{*}{ Service Sector } & $N$ & 2 & 2 & 1 & 1 & 1 \\
\hline & $\%$ & $40.0 \%$ & $40.0 \%$ & $20.0 \%$ & $20.0 \%$ & $20.0 \%$ \\
\hline \multirow[t]{2}{*}{ Governmental \& Military } & $N$ & 1 & 5 & 3 & 1 & 2 \\
\hline & $\%$ & $16.7 \%$ & $83.3 \%$ & $50.0 \%$ & $16.7 \%$ & $33.3 \%$ \\
\hline \multirow[t]{2}{*}{ Total } & $N$ & 7 & 11 & 4 & 5 & 5 \\
\hline & $\%$ & $41.2 \%$ & $64.7 \%$ & $23.5 \%$ & $29.4 \%$ & $29.4 \%$ \\
\hline
\end{tabular}

Note: When more than one application is in question, the total ratio may exceed $100 \%$ in the same line.

under special security measures by an authorized personnel. Frequent conduct of the related applications raises problems on originality and security of records in electronic environment (Table 31).

Of the case institutions 66.7\% from Education\&Research, 60\% from Service Sector, and 33.4\% from Governmental \& Military stated, by marking "agree" or "strongly agree", that there was a strong and unproblematic relation between records creating units and central archive. It is particularly noteworthy that more than half of the Governmental \& Military group has problems in relation between official units and records and archive centers. 33.3\% of Education\&Research group also draws attention to the problems (Table 32).
Relation and integration between information system and electronic records archive system used in institutions:

There are differences in the relation between information systems and archive systems used in institutions. In Service Sector in-house applications are predominantly used (80\%), while half of the Education\&Research and Governmental \& Military groups have separate records and archive programs. Ratio of using a system in which archive system is integrated with other information systems is under $21 \%$ in each three groups (Table 33 ).

Materials are placed into information and records centers of institutions within the framework of filing plan and classification system. Filing system is used more predominantly in Governmental \& Military group (83.3\%), while in other groups classifying and filing

Table 35

The system uses of organizing information and records

\begin{tabular}{|c|c|c|c|c|c|c|}
\hline & & Library of congress & Standard file plan & Institutional file plan & Dewey & Not systematic \\
\hline \multirow[t]{2}{*}{ Education\&Research } & $N$ & 3 & 0 & 2 & 0 & 1 \\
\hline & $\%$ & $50.0 \%$ & $0 \%$ & $33.3 \%$ & $0 \%$ & $16.7 \%$ \\
\hline \multirow[t]{2}{*}{ Service Sector } & $N$ & 1 & 1 & 1 & 1 & 1 \\
\hline & $\%$ & $20.0 \%$ & $20.0 \%$ & $20.0 \%$ & $20.0 \%$ & $20.0 \%$ \\
\hline \multirow[t]{2}{*}{ Governmental \& Military } & $N$ & 1 & 4 & 1 & 0 & 0 \\
\hline & $\%$ & $16.7 \%$ & $66.7 \%$ & $16.7 \%$ & $0 \%$ & $0 \%$ \\
\hline \multirow[t]{2}{*}{ Total } & $N$ & 5 & 5 & 4 & 1 & 2 \\
\hline & $\%$ & $29.4 \%$ & $29.4 \%$ & $23.5 \%$ & $5.9 \%$ & $11.8 \%$ \\
\hline
\end{tabular}


Table 36

Intension of the creating body to establish an integrated and centralized digital recordkeeping system, controlling all records of the organization in all media and form?

\begin{tabular}{|c|c|c|c|c|c|c|c|c|}
\hline & & Strongly agree & Agree & $\mathrm{N} / \mathrm{A}$ & Disagree & Strongly disagree & $\sum$ & S.D. \\
\hline \multirow[t]{2}{*}{ Education\&Research } & $N$ & 1 & 3 & 1 & 1 & 0 & & \\
\hline & $\%$ & $16.7 \%$ & $50.0 \%$ & $16.7 \%$ & $16.7 \%$ & $0 \%$ & 2.33 & 1.033 \\
\hline \multirow[t]{2}{*}{ Service Sector } & $N$ & 0 & 3 & 1 & 0 & 1 & & \\
\hline & $\%$ & $0 \%$ & $60.0 \%$ & $20.0 \%$ & $0 \%$ & $20.0 \%$ & 2.80 & 1.304 \\
\hline \multirow[t]{2}{*}{ Governmental \& Military } & $N$ & 0 & 2 & 1 & 3 & 0 & & \\
\hline & $\%$ & $0 \%$ & $33.3 \%$ & $16.7 \%$ & $50.0 \%$ & $0 \%$ & 3.17 & .983 \\
\hline \multirow[t]{2}{*}{ Total } & $N$ & 1 & 8 & 3 & 4 & 1 & & \\
\hline & $\%$ & $5.9 \%$ & $47.1 \%$ & $17.6 \%$ & $23.5 \%$ & $5.9 \%$ & 2.76 & 1.091 \\
\hline
\end{tabular}

Table 37

Do they need to modify the existing policies, procedures, and standards currently control or influence records creation, maintenance, preservation or use?

\begin{tabular}{|c|c|c|c|c|c|c|c|}
\hline & & Strongly agree & Agree & $\mathrm{N} / \mathrm{A}$ & Disagree & $\sum$ & S.D. \\
\hline \multirow[t]{2}{*}{ Education\&Research } & $N$ & 3 & 0 & 3 & 0 & & \\
\hline & $\%$ & $50.0 \%$ & $0 \%$ & $50.0 \%$ & $0 \%$ & 2.00 & 1.095 \\
\hline \multirow[t]{2}{*}{ Service Sector } & $N$ & 0 & 3 & 2 & 3 & & \\
\hline & $\%$ & $0 \%$ & $60.0 \%$ & $40.0 \%$ & $0 \%$ & 2.40 & .548 \\
\hline \multirow[t]{2}{*}{ Governmental \& Military } & $N$ & 2 & 3 & 0 & 1 & & \\
\hline & $\%$ & $33.3 \%$ & $50.0 \%$ & $0 \%$ & $16.7 \%$ & 2.00 & 1.095 \\
\hline \multirow[t]{2}{*}{ Total } & $N$ & 5 & 6 & 5 & 1 & & \\
\hline & $\%$ & $29.4 \%$ & $35.3 \%$ & $29.4 \%$ & $5.9 \%$ & 2.12 & .928 \\
\hline
\end{tabular}

methods are used equally. This shows that in information/records centers, sources are rather composed of records in Governmental \& Military group, while in other groups they are composed of various information sources (books, periodicals, documents, etc.). Again in Governmental \& Military group, ratio of providing information/records centers with source is as high as 50\% within the framework of retention plans. In Education\&Research group, purchasing holds an important place with the percentage of $50 \%$ in obtaining materials. Other choice is $20 \%$ and over for each three groups (Table 34).

Feature of records type comes into prominence in the organization and arrangement of information/records sources. In Governmental \& Military group, it is predominantly conducted within the framework of Standard File Plan with 66.7\%, while in Education\&Research it is carried out according to Library of Congress classification system. Each variant is observed to have equal ratios in Service Sector. Nevertheless, it is a serious problem that no system is used for the arrangement of information/records sources in 20\% of Service Sector and $16.7 \%$ of Education\&Research (Table 35).

Records creating units of institutions predominantly have positive expectations on setting up an integrated and centralized digital recordkeeping system within the institution ("agree" and "strongly agree" responses are totally 53\%). Most negative approach to such improvement came from Governmental \& Military group ("NA" and "disagree" responses are totally 66.7\%). It is significant that more than half of the groups stated that there was need for an integrated and central electronic recordkeeping system (Table 36).

An important majority of the groups think that there is need for modification of existing institutional policies, procedures, and standards for creation, maintenance, preservation or use of records. It is significant that $50 \%$ of Education\&Research group strongly need such a change. This ratio was also found to be over $29 \%$ in other groups. Ratio of those who assert that there is no need for readjustment of arrangements which determine procedures related to published electronic records is under $17 \%$ in each three groups. Arithmetic mean values are found to be 2 (agree), which supports the expectations. Arithmetic mean in Service Sector is found to be over N/A and close to Agree level (Table 37).

\section{Evaluation and conclusion}

Since early 20th century, Turkey has faced drastic changes in administrative organization and institutional structuring in parallel to the effect of modern administration and system approaches. In spite of standstill periods at certain times, the changes point at a long-term innovation in both public and private sector. As a part of these changes, information and records systems were revised and, as a result of this, the legal and administrative arrangements mentioned in this study were set up and put into effect. Today, records management studies are guided by electronic applications. Electronic applications which have rapidly become widespread in the West since mid-1990s was introduced to Turkey in early 2000s with a delay of some 5 years. In this context, many public services are currently conducted in electronic environment. Turkey is rapidly upgrading its place in e-government indexes. However, both structural and practical problems and deficiencies are needed to be handled seriously. The primary issue at this point is to determine to what extend the existing conditions meet the expectations. In that context results obtained from the analyses conducted in 17 institutions are as follows:

Service areas of the case institutions consist of information service, publishing, research, public services, medical services, advertising. These institutions are chosen at nearly equal rates from sectors under three groups: Education\&Research, Service Sector, and Governmental \& Military.

To evaluate generally, in a great majority of the institutions from three groups, the units responsible for information and records services have not decision-making and expending authority, which poses a serious problem. It is thought that information and records procedures can be conducted more efficiently through efficiency calculation and appropriate financial accounting in services. On one hand, the number of personnel responsible for information and records procedures is sufficient in each three groups, on the other hand, there are serious problems in the number of trained 
personnel in the institutions which belong to Service Sector and Governmental \& Military groups. Although Service Sector has the highest ratio of annual records creation, its personnel number is lower than that of Education\&Research. This shows that inequalities exist in personnel distribution. Again in the Service Sector, existing policies and administrative arrangements for information/records procedures prove to be more inefficient than other sectors.

Records are frequently used in daily affairs in the institutions from each three groups. Also, no serious problems are observed in systems for conventional (printed) information and records in each three groups. There is not any communication or coordination problem amongst units within the institutions. It is a positive fact that $47.1 \%$ of the institutions have at least one information and records manager. $79 \%$ of the case institutions conduct information/records procedures in electronic environment, which can be an evidence for how rapid the recent change has been. However, the system used by a great majority of the institutions, especially by those belong to Governmental \& Military Sector and Service Sector, in information/records procedures under electronic environment are too simple, and it is remote from professionalism. The institutions predominantly make use of electronic information/records systems for administrative transactions and controlling, user statistics and providing the required sources. It is a serious problem that half of the institutions belonging to Governmental \& Military group have not software applications for information processing. Again it is remarkable that none of the institutions serving in Governmental \& Military sector have software application for institutional transactions.

Only 35\% of the 17 case institutions have an identified records management system which is composed of functions from creation to disposition of records in electronic environment. Programs used in other institutions can meet some stages of life cycle. $76 \%$ of all institutions conduct their official records trafficking in printed environment. The institutions do not have any problem with technological infrastructure, while infrastructure facilities for electronic records management applications are insufficient in 53\% of them.

Target audience of the groups shows variation according to the service. In Education\&Research, the target audience is the general public, while it is various in-house units in Governmental \& Military group.

It is seen that while metadata information of records is identified in electronic systems, some information, in particular the related activities and summary information are missing. Although whole of the office applications are carried out in electronic environment in all institutions, it is a serious problem that there is no systematic way of retention for data on e-mails platforms through which institutions conduct in-house communication.

In the institutions, there are no problems of authorization, security, backup, and preservation for a long period in ERM applications. However, records procedures requiring original signature cannot be conducted in electronic environment, which is a problem need to be primarily handled. The most problematic group in long-term preservation is the Governmental \& Military. A great majority of the groups $(82.4 \%)$ keep their data in databases belonging to institutional information systems. Changes can be done on these data in various levels in a further time. Yet, each three groups have problems in various levels in authorization, security, and preservation of data integrity of these changes.

Institutions being part of the Governmental \& Military group draw attention to disconnection between information/records center and other official units, while other groups, in general, do not have such serious problems.

It is seen that there is no integrated structures, in general, between information and records management programs and other information systems. This situation may lead to several problems in processing of institutional information systems as a whole, conducting information and records procedures in coordination, and sharing the required information and records on time.

In institutions, information and records sources are arranged according to the structure of existing material. However, according to Table 31, the predominant materials used in Governmental \& Military group are records. As it can be inferred from other results, problems on records procedures are denser in this group. Nevertheless, more than $10 \%$ of institutions and $20 \%$ of Service Sector state that they do not have any systematic arrangement, which turns out to be a serious problem.

Institutions generally indicate that they need an integrated and centralized digital recordkeeping system in order for controlling all records of the organization in all media and form created and used within the scope of ERM. Yet, this ratio decreases to $33.3 \%$ in Governmental \& Military group. 83.3\% of the institutions belonging to Governmental \& Military group state, on the other hand, that there is need to modify the existing policies, procedures, and standards currently control or influence records creation, maintenance, preservation or use. This shows that Governmental \& Military group primarily needs to reorganize its own system. The ratio is $50 \%$ and over in other groups, which proves that they need such reorganization as well.

\section{Suggestions}

Nearly all of the case institutions intend to transfer the entire information and records applications into electronic environment. However, under the existing conditions, one of the most challenging problems is the lack of central institutions that would coordinate the applications. Initially, a unit bound to the central government needs to be established which would set up the infrastructure for electronic information/records applications, and coordinate, arrange and supervise them. The existing units within State Planning Organization can be made more active. Moreover, the following suggestions proposed within the framework of the findings obtained from the study are thought to be important to take into account:

1. Units of institutions responsible for information/records procedures should have the authority of decision-making and expending independently.

2. Institutions in need of professional personnel should be supported. It is important to take into account the distribution of workload in appointments.

3. An important rate of institutional workload has already been transferred into electronic environment. Administrative and legal arrangements, which would identify information/records procedures in electronic environment just as in the printed environment, should be put into effect as soon as possible.

4. The system used by institutions in electronic environment is nothing more than word processor. Other systems (particularly used in information centers) do not focus on information sources. Information systems for institutions should be developed including the modules such as information, records, document, human resources, administrative information systems and budget programs. Transition, information exchange, and inter operability should be enabled among modules within ERM.

5. Metadata fields used in identifying records should be expanded considering every fact, and it should be possible to monitor and preserve the entire in-house correspondence within the system.

6. Transferring official correspondences requiring original signature into electronic environment by using secure electronic signature should be attached priority. 
7. Disconnections between information/records centers and other units should be eliminated, and a harmonized and coordinated functioning should be enabled.

8. ERM applications used in institutions should be restructured providing an integrated and centralized digital recordkeeping system in order for controlling all records of the organization in all media and form.

It should be taken into account that, fulfilling the suggestions above will enable e-government and ERM applications to become more efficient, reliable and systematic in institutions which have already gained acceleration in Turkey, and to lead up to innovations and advances.

\section{References}

Bilişim'07. (2007). Değerlendirme Raporu. Available from: http://www.digitaldevlet. net/index.htm.

Duranti, Luciana. (2007). An overview of InterPARES 3(2007-2012). Archives E Social Studies, 1(1), 577-603.

Elektronik Belge Yönetimi Sistem Kriterleri Referans Modeli. (2005). Prepared by Hamza Kandur. İstanbul: Devlet Arşivleri Genel Müdürlüğü.

Greenwood, D. J., \& Levin, M. (2003). Reconstructing the relationships between Universities and Society through action research. UK: Sage.

Hatır, Hüseyin. (2005), Dıș ticarette e-devlet. Available from: http://www.tele.com. tr/blog_comment.asp?bi $=1410$.

InterPARES Project. (2008). The International Research on Permanent Authentic Records in Electronic Systems (InterPARES) 3 Project. Available from: http://www.interpares.org/.

InterPARES Project Organizational Policy. (2007). The International Research on Permanent Authentic Records in Electronic Systems (InterPARES).

Kandur, H. (2006). Elektronik belge yönetimi sistem kriterleri referans modeli. Istanbul: Devlet Arşivleri Genel Müdürlüğü. http://www.devletarsivleri.gov. tr/EBYS_v_2_0.pdf Accessed 01.06.07.

Law on E-Signature. (2004). Republic of Turkey Official Journal, No: 25355. January $23,2004,1-8$.

Law on Freedom of Information. (2003). Republic of Turkey Official Journal, No: 25269. October 24, 2003, 1-8.

Merkezi Kayıt Kuruluşu. (2008). Nitelikle Elektronik Sertifika Edinimi. Available from: http://www.mkk.com.tr/MkkComTr/assets/files/tr/yay/mektuplar/GM258.pdf.
McNiff, J., \& Whitehead, J. (2006). All you need to know about action research. London: Sage Publications.

Prime Ministry Circular on Standard File Plan. (2005). Republic of Turkey Prime Ministry General Directorate of Personnel and Principles, 320-3802, March 24, 2005 , $1-55$

Receiving Opinion of General Directorate of State Archives on Sorting and Disposing Procedures, Sending Annual Archives Activity Report Without Delay, Transfer of Board of Management or Similar Decisions and Archive Material in Old Turkish Without Delay to the State Archives. (1998). Prime Ministry Circular, No: 18975. October 20, 1998.

Regulation on Amending the Regulation on State Archiving Services. (2001). Republic of Turkey Official Journal, No: 24487. August 08, 2001, 95-100.

Regulation on Principles and Procedures for Application of the Law on Right of Information. (2004). Republic of Turkey Official Journal, No: 25445. April 27, 2004, $1-13$.

Regulation on Principles and Procedures to be Applied in Official Correspondence. (2004). Republic of Turkey Official Journal, No: 25658. December 02, 2004, 5-26.

Reuters News Agency. (2006). Arsiv hizmetlerini düzenleyen tasarı komisyonda kabul edildi. http://www.isbank.com.tr/reuters-haber-detay.asp?Document_ Header=nGOK438372. Accessed 04.04.06.

T.C. Adalet Bakanlığı. (2008). Ulusal Yargı Ă̆ı Projesi (UYAP). Available from: http:/। www.uyap.gov.tr/genelbilgi/genel.html.

T.C. Başbakanlık Dış Ticaret Müsteşarlığı. (2008). Dahilde İşleme Rejimi (DiR) Otomasyon Uygulaması. Available from: http://www.immib.org.tr dirweb/firma_kullanim_kilavuzu.pdf.

T.C. Bayındırlık ve İskân Bakanlı̆̆ı Tapu ve Kadasro Genel Müdürlüğü. (2008). Tapu Arşiv Otomasyonu. Available from: http://www.tkgm.gov.tr/ ana.php?Sayfa=projedetay\&ID=11.

T.C. Dışişleri Bakanlığı. (2008), E-konsolosluk. Available from: http://www. e-konsolosluk.net/.

T.C. Başbakanlık Gümrük Müsteşarlığı. (2008). Available from: https:// guvas.gumruk.gov.tr/

T.C. Maliye Bakanlığı Milli Emlak Genel Müdürlüğü. (2008). Milli Emlak Otomasyon Projesi. Available from: http://www.milliemlak.gov.tr/ projelerimiz/meop/prj_meop.htm.

T.C. Sanayi ve Ticaret Bakanlığı. (2008). Garanti, Muafiyet ve SSHYB eimza'l Isşlemler Kılavuzu (2007). Available from: https://e-imza.sanayi.gov. tr/webedit/klavuz.pd.

T.C. Sosyal Güvenlik Kurumu. (2008). Kurumunuz İnteraktif Uygulamaları. Available from: http://www.ssk.gov.tr/sgk/e-hizmet.html.

Türk Patent Enstitüsü. (2007). E-İmza İle Marka Başvurusu Hizmetinizde. Available from: http://www.turkpatent.gov.tr/portal/default2.jsp?sayfa=703\&haber=496

Türk Standartları Enstitüsü. (2007). Bilgi ve dokümantasyon-Elektronik belge yönetimi. (TSE 13298). http://www.tse.org.tr/Turkish/Abone/Standard Ara.asp?Durum=IcsTablosu\&Sira=1\&EskiKod=01.110 Accessed 12.08.07. 